Jpn. J. Oral Biol., 23 : 581-588, 1981.

\title{
成熟ラット切歯根端部の器官培養
}

\author{
加賀山 学金田一孝二 \\ 秋田博 敏 高 橋 則 男 \\ 東北大学歯学部口脫解剖学第 2 講座
}

〔受付 : 昭和56年 7 月 24 日]

\section{Enamel organs of adult rat incisors in organ culture}

\author{
Kagayama M., Kindaichi, K., Akita, H. and Takahashi, N. \\ Department of Anatomy, Tohoku University School of Dentistry \\ 4-1 Seiryocho, Sendai 980
}

[Accepted for publication July 24, 1981]

Key words : amelogenesis/organ culture/circumfusion system/adult rat incisor

\begin{abstract}
Enamel organs of adult rat incisors containing both undifferentiated and secretory ameloblasts, were cultivated by two different methods of organ culture; a modified Trowell's method and a circumfusion system. In the former, explants were placed on the medium-gas interface and supported by a small piece of lens paper on a stainless steel grid in a culture dish. They were cultivated in Trowell's T- 8 medium supplemented with $10 \mathrm{mM}$ HEPES buffer gassed with $95 \%$ air and $5 \% \mathrm{CO}_{2}$. Enamel, secretory ameloblasts and cells of stratum intermedium were present in the explants for periods up to 7 days. Tomes's processes of the ameloblasts were very short and only proximal parts of processes were observed. No further survival of ameloblasts were seen with this method.

The other method was a circumfusion system originally reported by Rose with some modifications. Instead of cellophane dyalysis membrane, Nuclepore filter $(0.2 \mu)$ was used as a membrane separating the explant and perfusing medium. The system contained only four chambers. The medium consisted of No. 199 supplemented with $15 \%$ calf serum and $10 \mathrm{mM}$ HEPES buffer. Using this circumfusion system, enamel and secretory ameloblasts remained even on the 21 th day in culture, which was the longest period in this study. The ameloblasts had typical Tomes's processes. The cells of the stratum intermedium invariably faced the filter and often showed cytoplasmic processes in the holes of the filter.
\end{abstract}

緒言

歯胚の培養に関する研究は数多く，細胞分化に おける上皮と間葉との相互作用，歯胚および歯の 組織から遊出する細胞の特性，および培養による 蒾胚の形態形成能などいくつかの重要な知見が得 られている2,9,10)。

仙台市星陵町 4-1 (广 980)
歯胚の器官培養では未分化な胎児の組織を材料 とし, より分化した器官への分化過程を in vitro で得て，その形態形成能や分化の機構を明らかに しょうとするものであるが，多くの報告 ${ }^{1,3,4,13,15)}$ ではエナメル芽細胞の到達可能な最高分化点はエ ナメル基質形成の初期にあたり，石灰化の有無に ついては一般に困難であるとされている。

一方器官培養の利用法として, すでに分化した 
組織を in vitro で維持し，その組織の機能の解 明に役立てようとする立場がある ${ }^{14)}$ が，歯の組織 についての検討はあまりなされていない。著者ら は in vitro での 分泌期エナメル芽細胞の形態お よび機能の維持の試みとして, 成熟ラット切歯の 根端部の器官培養を行い, 多少の知見を得たので 報告する。

\section{材料と方法}

培養材料として体重150 250g の成熟ラットの 下顎切歯根端部を用いた。ペントバルビタールに よる麻酔下で, カニューレを左心室から大動脈に 挿入し, Hanks 液で灌流脱血の 後下頇を摘出し

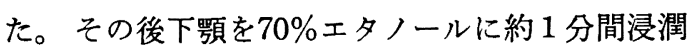
し Hanks 液で洗滌し，骨組織を取り去って切歯 を露出し, 根端部より約 $2 \mathrm{~mm}$ の長さに切断して 培養組織片とした。

器官培養法として, 静置法抢よび灌流法を用い た。静置法では $50 \mathrm{~mm}$ 径のシャーレを用い, その 中に下方からステンレス製の金網台，レンズペー パー, および組織片の順に重ね, 組織片が培地で ぬれる程度に培地を加えた。培地は HEPES 緩衝 液 $(10 \mathrm{mM})$ を加えた Trowell14) の T-8 用い, $95 \%$ 空気 $5 \% \mathrm{CO}_{2}$ の気相で培養し, 培地を 2 日 に 1 度交換して 1 週〜 3 週培養した。

灌流法は Rose ${ }^{8)} の$ circumfusion system に類 似の方法を用いたが，以下の点の改変を試みた。 Sykes and Moore ${ }^{12)}$ のチャンバー (*Belco 社, 外径32mm）を用い，下から順に plastic cover slip (Thermanox, Lux Scientific Corporation), 組織片, Nuclepore filter（厚さ $25 \mu$, 孔径 $0.2 \mu$, Nuclepore Corporation), シリコンガスケット, および plastic cover slip と重ね，その周囲をチ ヤンバー金具で封じた。シリコンガスケットで出 来る空間に注射針を介して培地を入れ，定流ポン プにより 1 個のチャンバーにつき $1 \sim 2 \mathrm{ml} / \mathrm{min}$ で灌流した。通常は 4 個のチャンバーが並列に 2 個の培地ビンに接続された。その他, 装置の保温, 炭酸ガスの供給は Rose R $^{8)}$ の方法に順じ，15\%子牛 血清を加え, HEPES 緩衝液 $(10 \mathrm{mM})$ で強化し

* Bellco Biological Glassware and Equiment, Vineland, N. J.
た No. 199培地》を用いて 1 週〜 3 週培羕を持続し た。培地は 7 日に 1 度, その半量 $(240 \mathrm{ml})$ を交 換した。

多くの場合培養組織はレンズペーパーまたは Nuclepore filter に付着したので，そのままの状 態で以下の処理を行った。組織片は燐酸緩衝液で $\mathrm{pH} 7.4$ に調製した $2 \%$ グルタールアルデヒドで前 固定, $1 \%$ 四酸化オスミウムで後固定の後, エタ ノール系列で脱水し，酸化プロピレンを経由して EPON に包埋された。その後約 $1 \mu \mathrm{m}$ 厚の切片を 作製して，これをトルイヂン青で染色して光線顕 微鏡で観察し, さらに超薄切片を作製して, 酢酸 ウラニルと鉛の電子染色の後, 電子顕微鏡で観察 した。

\section{結 果}

\section{静置培養}

培養期間 4 日〜 7 日では，分泌期のエナメル質 とエナメル芽細胞の形態維持が可能であった(Fig. 1，2，5）。エナメル芽細胞は背が高く，エナメル 質とエナメル芽細胞との境は不規則に波立ってお り, ラット切歯に特有の長い Tomes 突起は消失 していた。エナメル芽細胞の背の高さは不均一 で, 細胞質はトルヂン青に濃染する傾向が著明で ある。

電子顕微鏡による観察では, エナメル芽細胞の エナメル質側に明瞭な terminal webを認めた。 Terminal web よりエナメル質側の細胞質が電顕 的 Tomes 突起とされるが, in vivo で通常見ら れる小型の分泌顆粒や小胞はきわめて少い。部分 的に三角形の断面を示す Tomes 突起がエナメル 質に突出していた (Fig. 5)。その他のエナメル芽 細胞の細胞質には, ミトコンドリア, 粗面小胞体, 多数の脂肪滴，および少数の小型顆粒を含み，核 は細胞死の徵しとされる濃縮傾向を示さず，明瞭 な核小体を持つ。中間層細胞はほぼ正常に近く, 隣接細胞間に多数の微䋐毛様突起を示し, 細胞質 にはミトコンドリアと脂肪滴が認められた (Fig. 6)。エナメル質では針状結晶の分布が疎で，無構 造で電子密な基質に富む領域が，エナメル芽細胞 に近接して認められる(Fig. 5)。静置培養 2 週お よび 3 週ではエナメル質およびェナメル芽細胞を 
認めず， 組織は一部に未分化な上皮性細胞の小集 団を含み，その他の部位は未分化な結合組織で充 たされていた(Fig. 3)。

\section{灌流培養}

灌流培養法では培養 2 週および 3 週においても 分泌期に相当するエナメル芽細胞の維持が可能で あった。エナメル芽細胞は背の低い円柱状を呈し, Tome 突起に類似の細胞質突起を出している(Fig. $4,7,9)$ 。培養 2 週の組織では in vivo における 分泌期とほぼ類似の構造が観察された。すなわち Tomes 突起は 内部に少数の 小型顆粒, 小型小胞 およびミトコンドリアを含み，エナメル質は針状 結晶と結晶間を埋める基質，および stippled material を認める(Fig. 7)。一方培養 3 週の組織 では Tomes 突起は小型顆粒をほとんど含まず, ミトコンドリアや粗面小胞体が集積する部分と, 小器官をほとんど含まない部分とから成り，エナ メル質では基質および stippled material が消失 していた(Fig. 9)。

その他のエナメル芽細胞の細胞質および中間層 細胞は培養 2 週および 3 週で相違を認めなかっ た。すなわち前者にはミトコンドリア，粗面小胞 体，小型のゴルヂ装置および脂肪滴を認め，核の 位置は様々で, Tomes 突起直下に 位置すること もある。中間層細胞は，隔膜に用いた Nuclepore filter に必ず接して認められ，それ以外の方向に 組立てられた組織ではエナメル芽細胞の形態維持 が困難であった。隣接する中間層細胞間には少数 の微絨毛様突起が見られ，また Nuclepore filter の 孔の中にも細長い小突起をのばしていた(Fig. 8)。 さらに Nuclepore filter に接して一層の扁平な上 皮様細胞が遊出していた(Fig. 4)。

\section{考察}

歯の組織培養は種々の方法でなされてきたが, エナメル質の in vitro での形成は困難とされて いる ${ }^{2,9,103}$ 。 in vitroでのエナメル質形成の試みは 主として胎児の歯胚を用いた器官培養で行なわ $れ^{1,3,4,13,15)}$ エナメル質形成に必要な条件として酸 素濃度, $\mathrm{pH}$ の安定性, 胎児の血清または組織抽 出物, およびアスコルビン酸などの重要性が指摘 されている。胎児の歯胚の器官培養は細胞分化の
機序の解明にきわめて重要な研究方法であるが, 培養により到達できる最高分化点はエナメル質形 成の初期とされており, 分必期エナメル芽細胞の in vitro 実験法として不足の点が多い。その不足 をおぎなう一つの試みとして，すでに分泌期に分 化したエナメル芽細胞を含む成熟ラット切歯の根 端部の器官培羕が検討された。ラットの切歯は根 端部にエナメル芽細胞の増殖部を含み, 切端側へ 移動するにともない，分泌期および成熟期に変化 する。各々の機能相におけるエナメル芽細胞を in vitroで維持できれば，エナメル質形成の機序解 明にきわめて有効であると考えられる。

成熟ラット切歯の組織培養は Zussman $ら^{16)} の$ 分離培養に関する報告を見るのみで, 器官培養に ついての報告は見られない。Zussman ら ${ }^{16)}$ は成 熟ラット切歯のエナメル芽細胞を切り出し，これ を凝固血漿上で培養して, 主としてそこから遊出 する細胞を観察している。組織は凝固血漿が溶解 する 8〜10日目に細胞変性を認め,ついには necrosis に至ると報告している。

今回の実験では歯髄組織を含むラット切歯根端 部を切り出し, 2 種の器官培養法が試みられた。 静置法は Trowell1 ${ }^{14)}$ の器官培養の変法として広く 用いられ，歯胚の器官培養でもそれに類似の方法 が数多く発表され，その有用性が認められてい $ろ^{4,13,15)}$ 。胎坚性歯胚では培地は, MEM, BGJ 6 などに胎児の組織抽出物および胎児血清を加えて 使われているが，本実験では成熟動物の組織の形 態維持に有効とされるTrowell ${ }^{14)} の \mathrm{~T}-8$ 培地を基 本とし，これに緩衝系を強化した培地を用いた。 その結果 7 日間, エナメル質に接する上皮性細胞 の維持が可能であった。上皮性細胞は in vivoに おける分泌期エナメル芽細胞と比べて, 背の高さ が一様でない, 長い Tomes 突起が見られない, 分泌顆粒が少いなどの相違があるが，少数ながら 小型分泌顆粒が見られる事および分泌期のエナメ ル質とほぼ同じ形態を示すェナメル質に接する事 から分泌期に相当するエナメル芽細胞と考えられ る。

エナメル芽細胞は in vivo においても分泌期か ら一部の細胞死を含む移行期を経て成熟期に進 む ${ }^{6)} 。$ オートラヂオグラフィーによる研究では分 
泌期の期間は約 7 日間とされている ${ }^{111}$ が，今回維 持された期間はその日数にほぼ等しい。しかし器 官培養で維持されたエナメル芽細胞の基質形成機 能および石灰化機能の有無については今後の研究 課題として残されている。

灌流培養法は $\operatorname{Rose}^{81}$ により発表された方法で， 胎生組織の分化を発現させ，長期間の維持が可能 で，また培養期間中，位相差顕微鏡で観察可能と いう特徴を有している。しかしその原法によると 装置の準備およびチャンバーの組立てに熟練を要 するので, 本実験では組立てが容易な Sykes and $\mathrm{Moor}^{12)}$ 型のチャンバーを利用し，またチャンバ 一の数を少くして装置全体の組立てが短時間で出 来る様に配慮した。また予備的実験では Rose $^{8)} の$ 方法に従い，組織と灌流培地との間の隔膜として cellophane 膜を用いたが, 組織の形態維持が困難 であったので，これを Nuclepore filter におきか えた結果, 組織の維持が可能となった。Kumegawa ら cellulose acetate および reconstructed cellulose がより良い培養結果を示す事を報告している。今 回用いた膜は 透析膜ではなく, $0.2 \mu$ 径の孔を有 するフィルターなので Rose $\mathrm{e}^{8)}$ が指摘する組織産生 物を組織周囲に維持する透析膜の役割は，少くと も成熟動物の組織を用いた場合には必ずしも組織 の形態維持に重要でないものと考えられる。

灌流培養では静置培養に比べてより長期間の維 持が可能で, さらに Tomes 突起に類似の構造さ
え維持された。中間層細胞に相当する上皮性細胞 が，隔膜として用いた filter に必ず接して認めら れ，またそのように組立てられた組織片でのみエ ナメル武細胞の維持が可能であったが，これは in vivo における分泌期の中間層周囲に，密な毛 細血管網が発達する事と関連し，この時期の組織 代謝が活発である事が考えられる。

培養に用いられた組織は未分化な 細胞増殖部分 および分泌期エナメル芽細胞を含む領域の両者が 含まれるので，灌流培養法で維持されたエナメル 芽細胞の由来は 2 通りの由来が考えられるが，そ の点については従来用いられて来た胎児の歯胚で の検討が必要である。しかし灌流培養法は成熟動 物組織の形態維持に必要とされる酸素および栄養 の保給に有利であり，また組織を圧迫することに より末分化組織への逆もどり現象が抑制されるこ とが考えられ，今後エナメル質形成の in vitro 実験系として有効な手段である事が示唆された。

\section{結論}

ラット切歯根端部の器官培養により, 分泌期エ ナメル芽細胞の形態維持が可能であり，とくに灌 流培養法はその分化構造を長期間維持することが 示された。

（追記）本論文の要旨は第22回歯科基䃈医学会総会 (1980年10月・松戸) に扔いて発表した。ま た本研究の一部は文部省科学研究費, 昭和 55 年度一般研究 C 00557415の補助による。

抄録 : 分泌期エナメル芽細胞を含むラット切歯根端部の器官培養を行い，エナメル芽細胞の 形態維持につ いて検討した。

Trowell の T-8 培地を用いた静置培養法では, 培養 7 日までエナメル芽細胞, エナメル質および中間層 細胞を認めた。Tomes 突起は in vivo のそれに比べて短く, 突起の起始部のみが残存した。

灌流培養法は Rose の circumfusion system にほぼ準じたが, 組織片と灌流培地（子牛血清を加えた Medium 199）との隔膜に Nuclepore filter を用いて良い結果が得られた。培養期間14日および21日で Tomes 突起を有するエナメル芽細胞, エナメル質および中間層細胞の維持が可能であった。この事は灌流 培養法が分泌期エナメル芽細胞の長期間 in virro 実験系として有効な手段である事を示唆している。

\section{文献}

1) GLasstone, S. : The development of tooth germs in vitro, J. Anat. (London), $70: 260-$ 2661, 958.
2) Glasstone, S. : The development of tooth germs in tissue culture. in "Cells and Tissues in Culture, Methods Biology and Physiology." Vol. 2 (ed. by Willmer, E. N.), p. 273-283, Academic Press. London 
and New York, 1965.

3) HAY, M. F.: The development in vivo and in vitro of the lower incisor and molars of the mouse, Arch. Oral Biol., $3: 86-109$, 1961.

4) $\mathrm{KocH}$, W. E. : In vitro development of tooth rudiments of embryonic mice, Anat. Rec., 152 : 513-524, 1965.

5) Kumegawa, M., Nakamura, Y. and YAMADA, T.: Studies on the effect of selective membrane filtration on the differentiation of tissue culture, J. Cell Biol., 62 : 908-911, 1974.

6) MoE, H. : Physiological cell death of secretory ameloblasts in the rat incisor, Cell Tissue Res., 197 : 443-451, 1979.

7) Morgan. J. F., Morton, H. J. and ParKER, R. C.: Nutrition of animal cels in tissue culture, I. Initial studies on a synthetic medium, Proc. Soc. Exp. Biol. Med., 73 : 1-8, 1950.

8) Rose, G. G.: The circumfusion system for multipurpose culture chambers. I. Introduction to the mechanics, techniques, and basic results of a 12 -chamber (in vitro) closed circulatory system, J. Cell Biol., 32 : 89-112, 1967.
9) 佐藤温重 : 歯の組織培鿾, 硬組織研究（荒谷真 平他編） p. 20-31，医歯薬出版・東京. 1969.

10) Slavkin, H. C.: Amelogenesis in vitro. $J$. Dent. Res., 58(B) : 735-739, 1979.

11) Smith, C. E. and Warshawsky, H. : Cellular renewal in the enamel organ and odontoblast layer of the rat incisor as followed by radioautography using ${ }^{3} \mathrm{H}$-Thymidine. Anat. Rec., 183 : 523-562, 1975.

12) Sykes, J. A. and Moore, E. B. : A simple tissue culture chamber. Texas Rep. Biol. Med., 18 : 288-297, 1960.

13) TheslefF, I.: Differentiation of odontogenic tissue in organ culture. Scand. J. Dent. Res., 84 : 353-356, 1976.

14) Trowell, O. A.: The cultivation of mature organs in synthetic medium. Exp. Cell Res., 16 : 118-147, 1959.

15) Wigglesworth, D. J. : Formation and mineralisation of enamel and dentine by rat tooth germs in vitro. Exp. Cell Res., 49 : 211-215, 1968.

16) ZUSSMAN, W. V. and IOACHIM, H. I. : Growth of ameloblasts in vitro. II. Dental tissue culture studies. Lab. Invest., 13 : 887-893, 1964. 


\section{Explanation of Figures}

Fig. 1 The explant cultivated for 4 days in T-8. Thin layer of ameloblasts remains (upper left of the micrograph), and a small enamel organ is formed at lateral part of the explant. $\times 40$

Fig. 2 The explant cultivated for 7 days in T-8. Enamel and ameloblasts are seen, but Tome's processes are not obvious in this section. $\times 100$

Fig. 3 The explant cultivated for 14 days in T-8. There is no ameloblasts nor enamel in the explant. $\times 40$

Fig. 4 The explant cultivated for 21 days in a circumfusion system. Thin layers of enamel and ameloblasts can be observed in the area facing to the filter (arrowheads). $\times 100$

Fig. 5 Section showing Tome's processes of ameloblasts cultivated for 7 days in T-8. Tome's processes are very short and cell organelles are scare in them. $\times 6,000$

Fig. 6 Cells of stratum intermedium cultivated for 7 days in T-8. Cytoplasmic processes are seen between the neighbouring cells. $\times 6.000$

Fig. 7 Tome's processes of the ameloblasts cultivated for 14 days in a circumfusion system. A few secretory granules can be seen in Tome's processes. Enamel consists of ribbon-shaped crystals and electron dense matrix as immature enamel in vivo. Clumps of stippled material (arrowheads) are seen at base of the processes, $\times 10,000$

Fig. 8 Section through the cells of stratum intermedium after 14 days cultivation in a circumfusion system. Cytoplasmic processes of the cell are few between the neighbouring cells. Holes of the filter often contain cytoplasmic processes of the cell. (arrowheads). $\times 10,000$

Fig. 9 Tome's processes of ameloblasts cultivated for 21 days in a circumfusion system. Enamel consists of ribbon-shaped crystals. Note the absence of matrix in the enamel. $\times 15,000$ 


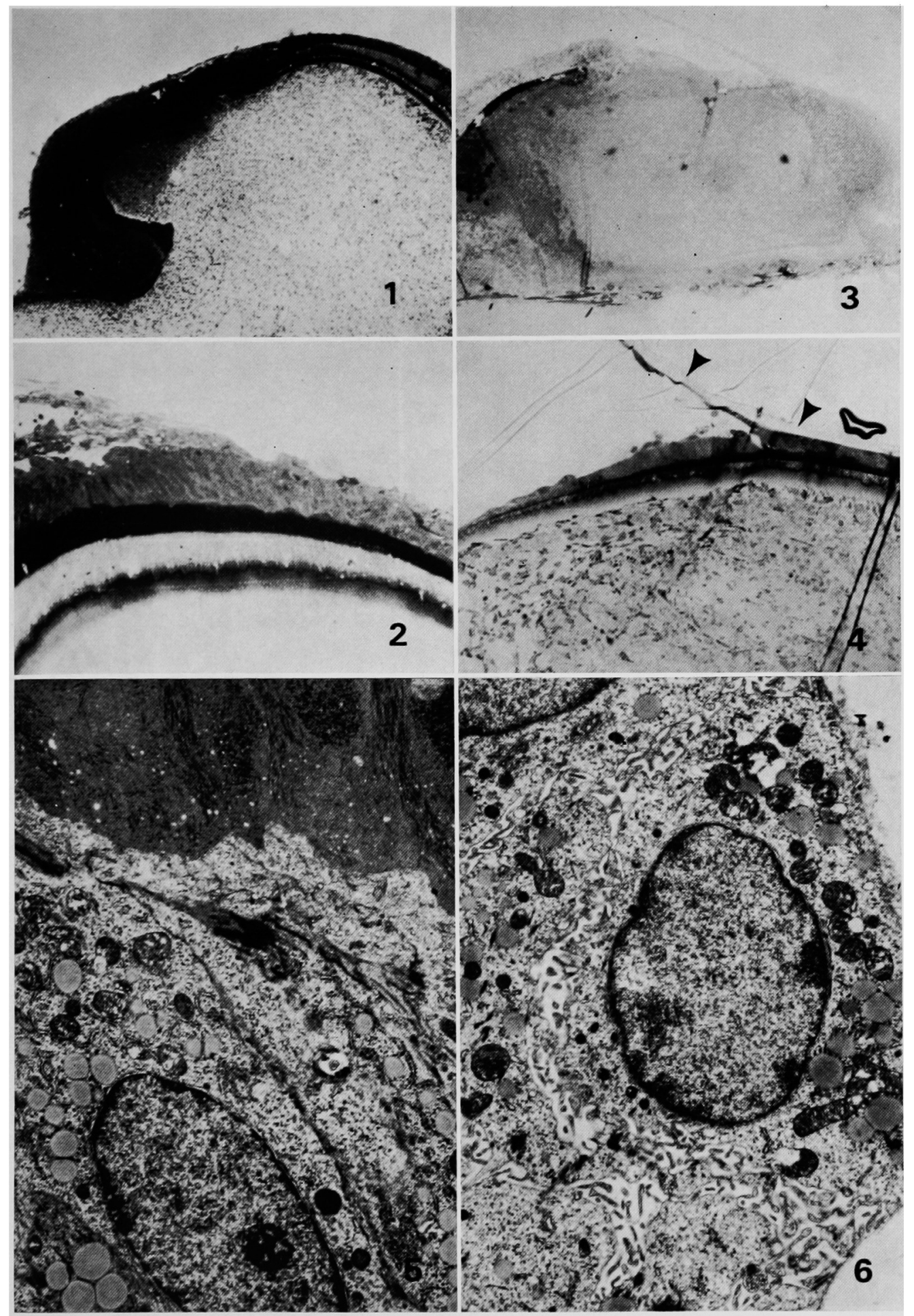




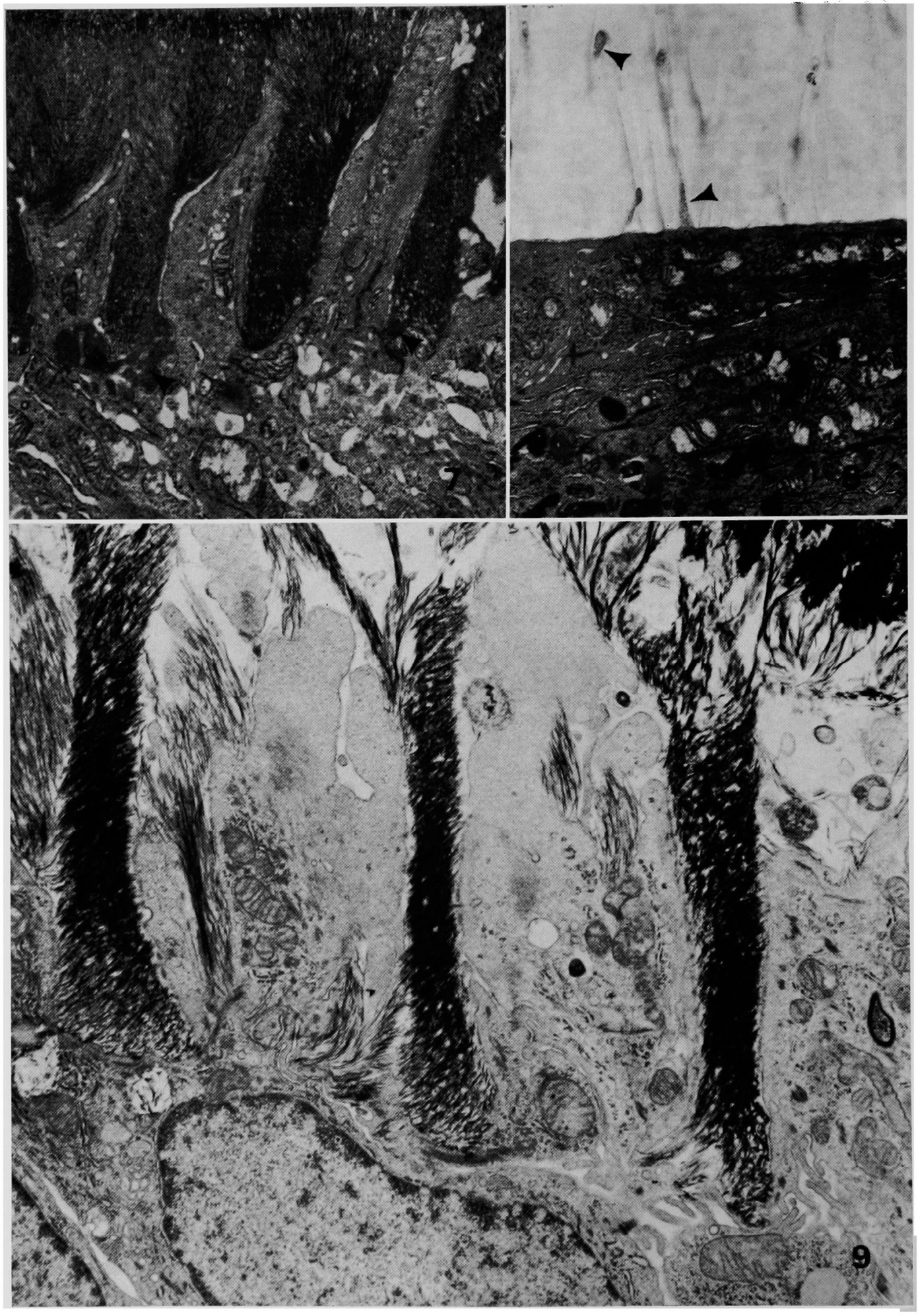

